IRA-International Journal of Education \& Multidisciplinary Studies ISSN 2455-2526; Vol.06, Issue 03 (2017) Pg. no. 209-217

Institute of Research Advances https://research-advances.org/index.php/IJEMS

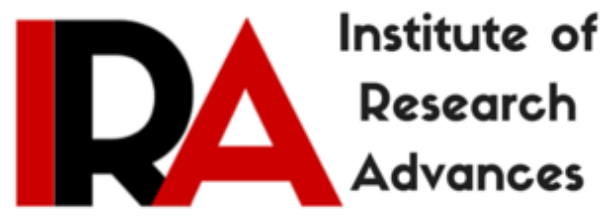

\title{
Attitude of School Teachers of Dooars Region of West Bengal towards Elementary Education
}

\section{Gour Sundar Ghosh}

Assistant Professor, Jalpaiguri A.C. College, \& Scholar, University of Kalyani, West Bengal, India.

\section{Prasenjit Deb ${ }^{\#}$}

Professor \& Head, Department of Lifelong Learning \& Extension, University of Kalyani, West Bengal, India.

${ }^{\#}$ Corresponding author.

Type of Review: Peer Reviewed.

DOI: http://dx.doi.org/10.21013/jems.v6.n3.p1

\section{How to cite this paper:}

Ghosh, G., \& Deb, P. (2017). Attitude of School Teachers of Dooars Region of West Bengal towards Elementary Education. IRA International Journal of Education and Multidisciplinary Studies (ISSN 2455-2526), 6(3), 209-217. doi:http://dx.doi.org/10.21013/jems.v6.n3.p1

(C) Institute of Research Advances

\section{(cc) BY-NC}

This work is licensed under a Creative Commons Attribution-Non Commercial 4.0 International License subject to proper citation to the publication source of the work.

Disclaimer: The scholarly papers as reviewed and published by the Institute of Research Advances (IRA) are the views and opinions of their respective authors and are not the views or opinions of the IRA. The IRA disclaims of any harm or loss caused due to the published content to any party. 


\begin{abstract}
Teachers are one of the most important components in education system. Apart from teaching learning, teachers are directly involved towards mental, physical, moral, spiritual, and psycho-social development of the students. This study conducted in Jalpaiguri, a Sarva Shiksha Mission (SSM) district of West Bengal to evaluate and assess the level of achievement earned by the Elementary Teachers from the SSM. While the level of attitude of school teachers towards elementary education $(Y)$ had been the dependent/predictor character $(Y)$, the contributory factors had been Age $\left(X_{1}\right)$, Education of teachers $\left(X_{2}\right)$, Training Experience $\left(X_{3}\right)$, Year of Experience $\left(X_{4}\right)$, Engagement in other activity $\left(X_{5}\right)$, Family Income $\left(X_{6}\right)$, Social Participation $\left(X_{7}\right)$, Interaction with Head Teacher $\left(X_{8}\right)$, Interaction with School Inspectors $\left(X_{9}\right)$, Interaction with SSM Personnel $\left(X_{10}\right)$, Organizational Interfacing $\left(X_{11}\right)$, Involvement in SSM activities $\left(X_{12}\right)$, Value Judgement $\left(X_{13}\right)$, Response about SSM activities $\left(X_{14}\right)$, Use of TL Materials $\left(X_{15}\right)$, Exposures to Media $\left(X_{16}\right)$, and Opinion about present education system $\left(X_{17}\right)$. The statistical analysis illustrated that while the variables: like (1) Education of teachers $\left(X_{2}\right)$, Engagement in other activity $\left(X_{5}\right)$, Family Income $\left(X_{6}\right)$, Social Participation $\left(X_{7}\right)$, Interaction with Head Teacher $\left(X_{8}\right)$, Use of TL Materials $\left(X_{15}\right)$ had wielded a substantive effect on the determining level of attitude of school teachers towards elementary education $(Y)$ and (2) variables: like Year of Experience (X4), Interaction with Head Teacher $\left(X_{8}\right)$ have been found to exercise significant regressional effect on the level of attitude of school teachers towards elementary education $(Y)$.
\end{abstract}

Keywords: Efficacy of SSM, Social Participation, Organizational Interfacing, Value Judgment and Opinion Matrix etc.

\title{
INTRODUCTION
}

Teachers play a great role not only in development and promoting positive attitude towards the value of education among the students and parents but also promote the human resource development among these sections. Keeping in view of the above, an attempt has been made to analyses the background characteristics of the teachers, their opinion towards the education of the scheduled castes (SC) and scheduled tribes (ST) children of the schools located in the SC, ST habitations or nearby habitations. The major problems encountered by the education system is enrolment of the children belonging to lower socio-economic status and retaining and enrolled children for a substantial period of time, keeping this is view, the teacher were enquired about difficulties experienced by them in enrolling and retaining the SC and ST children.

Goindaraju R. et al (2010) revealed in their study on school drop-outs in rural settings in rural areas of Chamrajanagar in Karnataka that neglect, poor or lack of interest of teachers, fear of teachers, misbehavior by teachers, irregular classes, poor teaching, overly strict discipline, discrimination, cruelty or punishment were given by teachers and absence of teachers or female teachers in school, etc were important reasons for dropouts. This study also showed non-enriched school environment, distance between homes to school, poor school maintenance, absence of toilets at school, intimidating system of examination, etc. also as reasons of school dropouts in their work.

Lessard A. et al (2010) conducted a study on Student-teacher relationship: A protective factor against school dropouts? This study analyzed the relationship between the student's commitment satisfaction, perceived achievement level, attitudes towards teachers, the perceived support and structure provided by teachers and the dropout risk. Result indicated that for boys, satisfaction and achievement contributed to explaining $18 \%$ of the variance whereas for girls, commitment, satisfaction and achievement explained $23 \%$ of the variance. Achievement represented a determinant factor while relationships did not contribute to the dropout risk for this sample. 
A study on the investigation of school-dropout at secondary level of formal education: the stated reasons by the school administrators and school counselors: a preliminary study was conducted by Kirazoglu C. (2009). It was a qualitative study. Semi-structured interviews were done with the administrators and counselors of 19 schools in Istanbul. The identified factors were academic failure, absenteeism, problems related with the elementary school system, adaptation problem, and the rules and regulations on academic success criteria.

Lessard A. et al (2008) conducted another study on Shades of discommitment: high school dropouts speak outll. They found in a qualitative study conducted using a sample of 32 dropouts, showing more specifically how certain factors such a conflicts with teachers affected both their achievement and decision to drop out.

Sharma R. et al (2007) found that school factors were responsible for girl's dropout such as discriminating behavior of teachers $(27.33 \%)$, insecure school environment $(24.33 \%)$, unsuitable school curriculum $(24.0 \%)$, rude behaviour of teachers $(22.0 \%)$, and absence of female teachers $(6.6 \%)$ in their study on Extent of female school drop outs in Kangra district of Himachal Pradesh.

In another study on School characteristics related to high school dropout rates done by Christle C. A. et al (2007) in Kentucky, USA. They compared the schools with higher dropout rates to schools with lower dropout rates in terms of the school characteristics. Academic difficulty, absenteeism, sense of belongingness to school and undesirable student behavior were some of the themes related with school dropouts.

Kotwal N. et al (2007), conducted a study on Causes of school dropouts among girls in Kathua District. This study conducted in Kathua District of Jammu \& Kashmir. In this study 4\% of the girls blamed the unfair behaviour of the teachers as a reason for leaving their studies. This study shows only $4 \%$ parents criticized the prevailing condition of schools.

A study on Dropout among girls at elementary level a study of casual factors by Roul K. et al (2005) revealed that school condition (61\%) also play important role in girl student's dropout. The school condition features distance of school from home, lack of teaching aids, teacher not understanding the needs and difficulties of students, punishment given by teacher etc. The sample comprised 100 teachers and 100 girl dropouts from the Sagobindpur block of Mayubhanj district of Orissa.

A more extensive study on predicting different types of school dropout: A typological approach with two longitudinal samples conducted by Janosz M et al (2000). They evaluated the influence of the studentteacher relationship on the dropout risk using a sample of 134 adolescents studying in schools located in impoverished communities. Their results indicate that warm relationships with teachers decreased the dropout risk of at-risk students whereas conflict relationships affected all students negatively.

A study on School related factors affecting the female school dropout phenomenon in rural areas was conducted by Saroja K. (1999). He revealed that seventy two percent of the teachers in schools were male and this could be the reason for girls to dropout. The purpose of this study was to analyze the structure of school education and the factors influencing female school dropouts in schools in Ron Taluka of Gadag district Karnataka. 
Desetty V. R. et al (1998) found that $61-86 \%$ slum children discontinued studies due to unaffordable school fees followed by improper teaching (45-61\%) and harassment by teacher (13-21\%) and teaching aids were also insufficient in their study on Slum school dropouts.

Panadya R. (1998) found most reported reason for dropping out of school was the boring teaching style(44\%) which was followed by reasons like physical punishment given by teacher (41\%), fear of failure (38\%), fear of teacher (22\%), Lack of toilet facilities (10\%), lack of drinking water facilities $(10 \%)$ , long distance between school and home and unable to follow classroom instruction (35\%) in his study Why do kids dropout of school in primary Municipal school of Baroda city.

Rumberger R. W. (1995) revealed the students who experience a warm relationship with their teacher are $16 \%$ less likely to drop out than students who report a negative relationship in his study on dropping out of middle school: A multilevel analysis of students and schools.

Pratinidhi A. K. et al (1992) depicted that Boys 13\% and girls 5\% left school because of harassment in school by teacher or classmates and boys (9\%) and girls (12\%) left school because of long distance in their study -Epidemiological aspects of school dropouts in children between 7-15 years in rural Maharashtra.

State Institute of Education (SIE) UP (1986) conducted a study on -A study of drop-outs and failures in primary classes. The main purpose of the study was to study the causes of drop-outs and failure among 6-14 years age students. This study revealed that main causes of dropouts were distance of school from home, unattractive environment of the school, indifference of teachers, irrelevant curriculum, lack of physical facilities like water and sanitation etc in schools.

Above studies discussed role of school and teachers as very important factor for school dropouts. Attitude and behavior of teacher, their way of punishment, irrelevant curriculum, boring teaching, lack of physical facilities, academic failure etc were identified as important reasons that for dropout. Lessard et al (2010) depicted that the teachers can play a role as protective factor in reducing school dropout.

\section{Objectives of the Study}

\section{General Objective:}

To study the level of attitude of school teachers towards elementary education.

\section{Specific Objectives:}

i. To evaluate and assess the level of achievement earned by the Elementary Teachers from the SSM;

ii. To assess the socio-personal and attitudinal casual variables viz. Age $\left(\mathrm{X}_{1}\right)$, Education of teachers $\left(\mathrm{X}_{2}\right)$, Training Experience $\left(\mathrm{X}_{3}\right)$, Year of Experience $\left(\mathrm{X}_{4}\right)$, Engagement in other activity $\left(\mathrm{X}_{5}\right)$, Family Income $\left(\mathrm{X}_{6}\right)$, Social Participation $\left(\mathrm{X}_{7}\right)$, Interaction with Head Teacher $\left(\mathrm{X}_{8}\right)$, Interaction with School Inspectors $\left(\mathrm{X}_{9}\right)$, Interaction with SSM Personnel $\left(\mathrm{X}_{10}\right)$, Organizational Interfacing $\left(\mathrm{X}_{11}\right)$, Involvement in SSM activities $\left(\mathrm{X}_{12}\right)$, Value Judgement $\left(\mathrm{X}_{13}\right)$, Response about SSM activities $\left(\mathrm{X}_{14}\right)$, Use of TL Materials $\left(\mathrm{X}_{15}\right)$, Exposures to Media $\left(\mathrm{X}_{16}\right)$, and Opinion about present education system $\left(\mathrm{X}_{17}\right)$. .

iii. To assess the nature, level and extent of inter dependence vis-à-vis mutual bearing taking ' $\mathrm{Y}$ ' (level of attitude of school teachers towards elementary education) as to be the consequent variable while the others ( mentioned in item - ii ) as explanatory variables . 


\section{THE STUDY AREA AND METHODOLOGY}

The present study is based on intensive house hold survey conducted during October - November 2016, in one block of the district of Jalpaiguri of the State of West Bengal. The block (Panchayat Samiti), namely Malbazar (North Circle) was selected at this phase apart from Matiali and Nagrakata, within 7 blocks in the district. Malbazar (North Circle) Block has Six Gram Panchayats and for this study to understand the problem we have covered all the Six (06) Gram Panchayats (GPs) viz. Rungamuttee, Oodlabari, Damdim, Kumlai, Tesimla, Bagracote of the Malbazar (North Circle) Block. During selection of school teachers those schools were given preferences where dropout rate was below $50 \%$. A structured schedule containing 22 different questions / statements / views were placed before each respondent teacher separately to measure the level of Effectiveness of SSM. Here, in order to explore the problem, different statistical methods like correlation, regression, and step down regression have been adopted.

\section{RESULT AND DISCUSSION:}

Table-I: Coefficient of correlation between Y and other 17 independent variables

\begin{tabular}{|c|c|c|}
\hline $\begin{array}{l}\text { Sl. No. } \\
X_{1}\end{array}$ & $\begin{array}{c}\text { Variables } \\
\text { Age of respondent }\end{array}$ & $\begin{array}{l}\text { "r" value } \\
-.1136\end{array}$ \\
\hline $\mathbf{X}_{2}$ & Education of teachers & $0.2570 * *$ \\
\hline $\mathrm{X}_{3}$ & Training Experience & 0.1371 \\
\hline $\mathrm{X}_{4}$ & Year of Experience & 0.0148 \\
\hline $\mathrm{X}_{5}$ & Engagement in other activity & 0.1919 \\
\hline $\mathbf{X}_{6}$ & Family Income & $-.2033 *$ \\
\hline $\mathbf{X}_{7}$ & Social Participation & $0.2391 * *$ \\
\hline $\mathbf{X}_{8}$ & Interaction with Head Teacher & $0.2385 * *$ \\
\hline $\mathrm{X}_{9}$ & Interaction with School Inspectors & 0.1228 \\
\hline $\mathrm{X}_{10}$ & Interaction with SSM Personnel & 0.1296 \\
\hline $\mathrm{X}_{11}$ & Organizational Interfacing & 0.1505 \\
\hline $\mathrm{X}_{12}$ & Involvement in SSM actions & 0.1496 \\
\hline $\mathrm{X}_{13}$ & Value Judgement & 0.0928 \\
\hline $\mathrm{X}_{14}$ & Response about SSM activities & 0.0812 \\
\hline $\mathbf{X}_{15}$ & Use of TL Materials & $0.2917 * *$ \\
\hline $\mathrm{X}_{16}$ & Exposures to Media & -.0833 \\
\hline $\mathrm{X}_{17}$ & Opinion about present education system & 0.0230 \\
\hline
\end{tabular}

Table I presents the correlation studies between the dependent variable i.e. level of Attitude of School Teacher towards elementary education $(\mathrm{Y})$ and other seventeen (17) independent variables viz. Age $\left(\mathrm{X}_{1}\right)$, Education of teachers $\left(\mathrm{X}_{2}\right)$, Training Experience $\left(\mathrm{X}_{3}\right)$, Year of Experience $\left(\mathrm{X}_{4}\right)$, Engagement in other activity $\left(\mathrm{X}_{5}\right)$, Family Income $\left(\mathrm{X}_{6}\right)$, Social Participation $\left(\mathrm{X}_{7}\right)$, Interaction with Head Teacher $\left(\mathrm{X}_{8}\right)$, Interaction with School Inspectors $\left(\mathrm{X}_{9}\right)$, Interaction with SSM Personnel $\left(\mathrm{X}_{10}\right)$, Organizational Interfacing 
$\left(\mathrm{X}_{11}\right)$, Involvement in SSM Components $\left(\mathrm{X}_{12}\right)$, Value Judgement $\left(\mathrm{X}_{13}\right)$, Response about SSM activities $\left(\mathrm{X}_{14}\right)$, Use of TL Materials $\left(\mathrm{X}_{15}\right)$, Exposures to Media $\left(\mathrm{X}_{16}\right)$, and Opinion about present education system $\left(\mathrm{X}_{17}\right)$. It is found that variables like Education of teachers $\left(\mathrm{X}_{2}\right)$, Family Income $\left(\mathrm{X}_{6}\right)$, Social Participation $\left(\mathrm{X}_{7}\right)$, Interaction with Head Teacher $\left(\mathrm{X}_{8}\right)$, and Use of TL Materials $\left(\mathrm{X}_{15}\right)$ had wielded a substantial influence on the dependent variable that is, level of attitude of school teachers towards elementary education.

Higher educational qualification $\left(\mathbf{X}_{2}\right)$ means enrichment in academic arena in terms of innovations, new experiences; deeper understanding in subjects and better output in classroom teaching and accordingly teachers could have associated themselves in the participatory interacting during different training programmes. As a result, they built up higher effectiveness index towards implementation of Sarva Shiksha Mission objectives. Also the higher educational qualification leads the more salary of a school teacher. So the higher family income $\left(\mathrm{X}_{6}\right)$ makes the mind of a teacher to think independently for the cause elementary education.

Engagement in allied activities like a member of office bearer of Panchayat Raj Institutions/ Municipality/ School organization/ NGO/Co-operative/ Club or any other organization in short, social participation $\left(\mathbf{X}_{7}\right)$ helped teachers in utilizing their diverse access in institutional and interpersonal interactions. These have contributed to build up a wide range of inventory information on different aspects of education during SSM.

Head teachers or Head Masters/Mistresses play an important role in their school environment. School teachers are generally busy with their class teaching. So Head teachers or Head Masters/Mistresses are the persons who are in contact most of the times with their Teachers and other educational administrators of the district. Hence, the interaction of teacher with Head Teacher $\left(\mathbf{X}_{\mathbf{8}}\right)$ makes it easier for better implementation of SSM programmes.

Teaching Learning Materials (TLM) cannot be invented from the market rather it is articulated within teachers' innovations. It is the teacher who ultimately invented and use of TL Materials $\left(\mathbf{X}_{\mathbf{1 5}}\right)$ during class room teaching which ultimately influenced learning effectiveness index and impart quality of education.

Table II: The Multiple Regression Analysis

$\begin{array}{llccc}\text { Sl. No. } & \text { Variables } & \mathbf{c} \boldsymbol{\beta} \text { ” value } & \text { “t” value } & \\ \mathrm{X}_{1} & \text { Age of respondent } & -.193429 & & -1.391 \\ \mathrm{X}_{2} & \text { Education of teachers } & 0.212273 & 1.984 & \\ \mathrm{X}_{3} & \text { Training Experience } & 0.046394 & 0.440 & \\ \mathbf{X}_{\mathbf{4}} & \text { Year of Experience } & \mathbf{0 . 3 2 8 4 4 4} & \mathbf{2 . 2 0 0 *} & \\ \mathrm{X}_{5} & \text { Engagement in other activity } & 0.166118 & 1.711 & \\ \mathrm{X}_{6} & \text { Family Income } & -.185251 & & -1.819 \\ \mathbf{X}_{\mathbf{7}} & \text { Social Participation } & \mathbf{0 . 2 3 9 0 0 0} & \mathbf{2 . 4 5 4} * & \\ \mathbf{X}_{\mathbf{8}} & \text { Interaction with Head Teacher } & \mathbf{0 . 2 1 2 1 6 4} & \mathbf{1 . 9 9 9 *} & \\ \mathbf{X}_{9} & \text { Interaction with School Inspector } & -.005825 & & -.045\end{array}$


$\mathrm{X}_{10} \quad$ Interaction with SSM Personnel

0.129614

$-.051653$

0.008504

0.168313

0.035284

0.167512

$-.187154$

$-.032792$
1.022

0.061

1.754

0.368

1.648

$-1.710$

$-.355$

Multiple R $=0.59733$

R Square $\quad=0.35680(35.68 \%)$

Adjusted $R^{2}=0.22345$

Standard Error $=1.17416$

Analysis of Variance

$\begin{array}{llcl} & \text { DF } & \text { Sum of Squares } & \text { Mean Square } \\ \text { Regression } & 17 & 62.71091 & 3.68888 \\ \text { Residual } & 82 & 113.04909 & 1.37865\end{array}$

$F=2.67572$ Signif $F=.0016$

Table II presents the multiple regression analysis with $\beta$ values and corresponding $t$ values. It is discernible that the variables like Year of Experience $\left(\mathrm{X}_{4}\right)$, Interaction with Head Teacher $\left(\mathrm{X}_{8}\right)$ have been found to exercise significant regressional effect on the level of attitude of school teachers towards elementary education.

It has been found that the different factors affecting the level of Attitude of school teachers towards elementary education. It is also to be mentioned that all eighteen variables put together can explain 35.68 per cent $\left(\mathrm{R}^{2}=0.35680\right)$ of the total effect. This demands inclusion of more variables as well as more number of respondents for being studied across the heterogeneous micro situations to generate higher levels of explicability.

\section{Table 3: Step down Regression Analysis}

\section{Variable(s) Entered on Step Number}

1. $\mathrm{X}_{15}$

Multiple R $=0.29172$

R Square $\quad=0.08510$

Adjusted $\mathrm{R}^{2}=0.07576$

Standard Error $=1.28096$

\section{Variable(s) Entered on Step Number}

\section{2. $\mathrm{X}_{7}$}

Multiple $\mathrm{R}=0.37369$

$\mathrm{R}$ Square $\quad=0.13964$

Adjusted $\mathrm{R}^{2} \quad=0.12190$ 
Standard Error $=1.24857$

\author{
Variable(s) Entered on Step Number \\ 3. $\mathrm{X}_{2}$ \\ Multiple $\mathrm{R} \quad=0.45001$ \\ R Square $\quad=0.20251$ \\ Adjusted $\mathrm{R}^{2} \quad=0.17759$ \\ Standard Error $=1.20833$
}

From placing the variables into a step down model of regression analysis, it is found that after step 3, three variables viz. of Education of teachers $\left(\mathrm{X}_{2}\right)$, Social Participation $\left(\mathrm{X}_{7}\right)$, Use of TL Materials $\left(\mathrm{X}_{15}\right)$ summated had explained 20.25 per cent of the total effect. Thus, rest 14 variables were explaining only about 15.43 per cent of total effect. It is interesting to note that in the step down model, role of teachers had come up innovatively to characterize the agglomerated effect of these three variables on the level of attitude of school teachers towards elementary education in the study area.

\title{
Conclusion
}

Education is a multidimensional process. It is a form of learning in which the knowledge, skills, and habits of a group of people are transferred from one generation to the next through teaching, training, or research. Education frequently takes place under the guidance of others, and hence the role of teacher is significant. Sarva Shiksha Mission is the path way through which the existing educational system can get fillip to achieve the objectives of universalization elementary education. The Efficacy of Sarva Shiksha Mission is the amalgamated goal to be achieved from stake holders like students and parents, society, education managers, and teachers. Among them, teachers' role is very essential in the sense that the teacher alone can do the stirring components towards triumph of the objectives of the task. So the consideration of Efficacy of Sarva Shiksha Mission from teacher's psychoanalysis is essential.

\section{Reference:}

1. Christle C. A. Joiivette K. \& Nelson C.M. (2007). School Characteristics related to High School Dropout Rates, Remedial and Special Education, Volume 28, Number 6, 325-339.

2. Deb, P. \& Acharjee, S.K.(2002).Teachers' Perception on DPEP - A multidimensional study on Cooch Behar. J. Interacademicia. No. 6(2). pp. 226-231.

3. Desetty V. R., Pantnam N.V. and Gaikwad R. S. (1998). Slum School Dropouts, Social Welfare, June 20-21.

4. Govindaraju R. and Venkatesan S.(2010). A Study on school dropouts in rural setting, Journal Psychology, published by kamla raj enterprises 1 (1) 47-53.

5. Janosz, M., LeBlanc, M. Boulerice, B. and Tremblay, R. (2000). Predicating different types of school dropout: A typological approach with two longitudinal samples, Journal of Educational Psychology 92 (I), 171-190.

6. Kirazoglu C. (2009). The investigation of school-dropout at the secondary level of formal education: the stated reasons by the school administrators and school counselors: a preliminary study, Procedia social and Behavioral sciences I, 905-914. 
7. Kotwal N.,Neelima, Rani S.(2007). Causes of school dropouts among girls in Kathua District, Journal Human Ecology, 22 (1) 57-59.

8. Lessard A., Poirier M. and Fortin L. (2010). Student-teacher relationship: A protective factor against school dropout? Procedia Social and Behavioral Sciences 2, 1636-1643.

9. Lessard, A., Butler-Kisber, L., Fortin, Royer, E. Marcotte,D. and Potvin P. (2008). Shades of discommitment: High school dropouts speak out, Social Psychology of education,11, 25-42.

10. Pandya R. (1998) — Why do kids drop out of school? Social welfare, June, 16-19.

11. Pratinidhi K. A. Kurulkar, V. P.Garad G. S. and Dalal M.(1992). Epidemiological Aspects of school dropouts in children between 7-15 years in Rural Maharashtra, Indian Journal Pediatrics, Vol-59,(4), 423-427.

12. Roul K. S. and Sahoo N. R. (2005). Dropout Among Girls At Elementary level A study of casual Factors, Journal of community guidance \& research, November, Vol 22, 292-298.

13. Rumberger R. W. (1995). Dropping out of middle school: A multilevel analysis of students and schools, American Educational Research Journal 32, 583-625. Rush S. and Vitale A. P. (1994).

14. Saroja K. (1999) - School related factors affecting the female school dropout phenomenon in rural area - A case study, Journal of Education and Social change 12 (14), 28-37.

15. Sharma., R., Sharma S., and Nagar S.(2007). Extent of female school dropouts in Kangra District Of Himachal Pradesh, Journal Social sciences, published by kamla raj enterprises 15 (3) 201-204.

16. SIE U.P. (1986). A study of dropouts and failures in Primary classes, Allahabad, BUCH M.B., fourth survey of research in Education, 1281. 